\title{
Transcriptional profile of Paracoccidioides induced by oenothein $B$, a potential antifungal agent from the Brazilian Cerrado plant Eugenia uniflora
}

\author{
Patrícia Fernanda Zambuzzi-Carvalho ${ }^{1}$, Patrícia Kott Tomazett ${ }^{1}$, Suzana Costa Santos ${ }^{2}$, Pedro Henrique Ferri ${ }^{2}$, \\ Clayton Luiz Borges ${ }^{1}$, Wellington Santos Martins ${ }^{3}$, Célia Maria de Almeida Soares ${ }^{1}$ and Maristela Pereira ${ }^{*}$
}

\begin{abstract}
Background: The compound oenothein B (OenB), which is isolated from the leaves of Eugenia uniflora, a Brazilian Cerrado plant, interferes with Paracoccidioides yeast cell morphology and inhibits 1,3- $\beta$-D-glucan synthase (PbFKS1) transcript accumulation, which is involved in cell wall synthesis. In this work we examined the gene expression changes in Paracoccidioides yeast cells following OenB treatment in order to investigate the adaptive cellular responses to drug stress.

Results: We constructed differential gene expression libraries using Representational Difference Analysis (RDA) of Paracoccidioides yeast cells treated with OenB for 90 and 180 min. Treatment for 90 min resulted in the identification of 463 up-regulated expressed sequences tags (ESTs) and 104 down-regulated ESTs. For the 180 min treatment 301 up-regulated ESTs and 143 down-regulated were identified. Genes involved in the cell wall biosynthesis, such as GLN1, KRE6 and FKS1, were found to be regulated by OenB. Infection experiments in macrophages corroborated the in vitro results. Fluorescence microscopy showed increased levels of chitin in cells treated with OenB. The carbohydrate polymer content of the cell wall of the fungus was also evaluated, and the results corroborated with the transcriptional data. Several other genes, such as those involved in a variety of important cellular processes (i.e., membrane maintenance, stress and virulence) were found to be up-regulated in response to OenB treatment.
\end{abstract}

Conclusions: The exposure of Paracoccidioides to OenB resulted in a complex altered gene expression profile. Some of the changes may represent specific adaptive responses to this compound in this important pathogenic fungus.

Keywords: Paracoccidioides, Antifungal, Oenothein B, Transcriptome, Cell wall

\section{Background}

Opportunistic and invasive fungal infections have become an important cause of morbidity and mortality [1]. The alarming rates of emerging antifungal resistance in hospitals are major concerns to the public health and scientific communities worldwide [2]. The most common antifungals currently used in the treatment of mycosis have some limitations, such as toxicity [3]. Considering all of these circumstances together has led

\footnotetext{
* Correspondence: maristelaufg@gmail.com

'Departamento de Bioquímica e Biologia Molecular, Laboratório de Biologia Molecular, Instituto de Ciências Biológicas, ICBII, Campus II, Universidade Federal de Goiás, C.P. 131, 74001-970 Goiânia, GO, Brazil

Full list of author information is available at the end of the article
}

to an urgent need for the identification of new and more effective antifungal agents.

Plants provide unlimited opportunities for the isolation of new antifungal compounds because of the unmatched availability of chemical diversity [4]. In fact, numerous antifungal compounds have been isolated from them [5-7]. The leaves of Eugenia uniflora L (Myrtaceae), known as the Brazilian cherry tree or pitangueira, are used in infusions or decoctions in popular medicine to treat inflammations associated with rheumatic pains and fever, hypoglycemia, as a diuretic and to prevent stomach diseases [8]. The hydroalcoholic extract from leaves decreased the levels of the enzyme

\section{Biomed Central}


xanthine oxidase, which is believed to be involved in the development of gout [9] in addition to its antioxidant and anti-inflammatory actions [10]. The enzyme also has anti-diarrheal [11], antihypertensive [12] actions and anti-microbial properties [13]. The Brazilian cherry tree is mentioned in the fourth edition of the Brazilian Pharmacopoeia [14], and the leaves are on the list of medicinal plants authorized by the Ministry of Health (ANVISA) with which to prepare infusions, as seen in the Brazilian Resolution number 267 [15].

Oenothein B (OenB) is a macrocyclic hydrolyzable tannin dimer isolated from E. uniflora leaves and possesses antimicrobial [16] and anti-tumor activities $[17,18]$ and anti-inflammatory and anti-oxidant properties [10]. Bio-guided assays with leaves from E. uniflora showed that OenB inhibited Paracoccidioides growth and the accumulation of 1,3- $\beta$-D-glucan synthase (PbFKS1) transcripts, which synthesizes 1,3- $\beta$-D-glucan polymer that is deposited in the fungus cell wall [19].

Paracoccidioides is a thermodimorphic fungus and is the etiologic agent of paracoccidioidomycosis (PCM), an important mycosis in Latin America. The infection is caused by the inhalation of the fungal spores, after which the fungus is able to disseminate from the lungs through the lymphatic system or the bloodstream to any organ or system [20]. The initial treatment of PCM depends on the severity of the disease and may last from 2 to 6 months. Extended periods of treatment, up to 2 or more years, are often necessary with a significant frequency of relapsing disease [21,22].

Several studies have been performed to investigate the transcriptional profile of the fungus in order to elucidate the mode of action of candidate drug compounds [23-26]. Here, cDNA libraries were constructed to obtain expressed sequences tags (ESTs) of Paracoccidioides. The Representational Difference Analysis (RDA) technique was used to identify changes in the transcriptional profile of Paracoccidioides in response to OenB, aiming to identify the probable mode of action of the compound in the fungus. Transcript levels were also measured during the infection process. In addition, the cell wall polymer levels were examined in members of the Paracoccidioides complex.

\section{Results}

\section{Libraries characteristics}

Cell viability was measured after exposure to OenB. A viability of $75 \%$ and $85 \%$ (data not shown) corresponding to the 90 and $180 \mathrm{~min}$ treatments, respectively, were chosen for RNA extraction and library construction. The libraries were constructed using the RDA technique, which is able to identify both up- and down-regulated differentially expressed genes between two cDNA populations [27]. The RDA experimental design included two conditions: (i) Paracoccidioides yeast cells exposed to McVeigh Morton (MMcM) medium with $0.32 \mathrm{M}$ OenB for 90 and $180 \mathrm{~min}$ and (ii) Paracoccidioides yeast cells grown in MMcM medium for 90 and $180 \mathrm{~min}$. For the up- regulated gene library construction, the first condition (i) was used as a tester population and the latter (ii) as the driver population. However, for the downregulated library construction, the former (i) was used as the driver population and the latter (ii) as the tester population. Subtractions were performed by incubating the driver and tester populations. The selection of the cDNAs was achieved by constructing subtracted libraries in pGEM-T Easy, as described in the Methods section.

\section{Bioinformatics results for libraries exposed to OenB}

RDA analysis revealed that a large number of ESTs (1011) was differentially regulated in the four gene libraries constructed after OenB treatment. From the RDA library of yeast cells exposed to OenB for $90 \mathrm{~min}$ 463 up-regulated and 104 down- regulated genes were identified. After pipeline analysis, the 463 up-regulated sequences originated 36 contigs and 20 singlets; the 104 down-regulated sequences originated 12 contigs and 7 singlets. The same analysis was performed for the RDA library obtained from yeast exposed to OenB for $180 \mathrm{~min} ; 301$ up-regulated and 143 down-regulated genes were identified from this library. After pipeline analysis, the 301 up-regulated sequences formed 14 contigs and 8 singlets; the 143 down-regulated sequences formed 12 contigs and 6 singlets. The ESTs obtained were submitted to the National Center for Biotechnology Information (NCBI) under accession numbers: LIBEST_028147 Paracoccidioides oenoteinB 90up Library, LIBEST_028146 Paracoccidioides oenoteinB 90 down Library, LIBEST_028149 Paracoccidioides oenoteinB 180 up Library and LIBEST_028148 Paracoccidioides oenoteinB 180down Library.

All of these up- and down-regulated ESTs after 90 and $180 \mathrm{~min}$ of exposure to OenB were compared to Paracoccidioides genes in the database of the Broad Institute by using the Blast X program. ESTs with evalue $<10^{-5}$ were considered in this analysis. All the obtained contigs and singlets were annotated by using the Blast2GO program. Based on this annotation, the ESTs represented in the four libraries were grouped into the functional categories according to the classification of GO. The ESTs were related with metabolism, energy, transcription, signal transduction, protein fate, protein synthesis, morphology, transport, cell cycle and DNA processing, cell rescue, defense and virulence, functionally unclassified proteins and unclassified proteins (Table 1).

Graphs were plotted to demonstrate the statistically enriched GO functions with up- or down-regulated 
Table 1 Annotated ESTs up and down regulated genes of Paracoccidioides yeast cells treated with OenB by 90 and $180 \mathrm{~min}$

\begin{tabular}{|c|c|c|c|c|c|}
\hline \multirow[t]{2}{*}{ Functional category } & \multirow[t]{2}{*}{ Gene product } & \multirow[t]{2}{*}{$\begin{array}{l}\text { Paracoccidioides } \\
\text { acession number }^{a}\end{array}$} & \multirow[t]{2}{*}{ e-value } & \multicolumn{2}{|c|}{$\begin{array}{l}\text { Number of } \\
\text { occurrence }\end{array}$} \\
\hline & & & & $90 \mathrm{~min}$ & $180 \mathrm{~min}$ \\
\hline \multicolumn{6}{|l|}{ Metabolism } \\
\hline \multirow[t]{3}{*}{ Amino acids metabolism } & Alanine glyoxylate aminotransferase (AGX1) & PAAG_03138.1 & $1 e-152$ & +2 & -1 \\
\hline & Hexokinase 1 (HXK1) & PAAG_01377.1 & $2 e-48$ & +2 & \\
\hline & Urease (URE) & PAAG_00954.1 & 0.0 & +1 & \\
\hline \multirow[t]{4}{*}{ Carbohydrate metabolism } & Betaine aldehyde dehydrogenase (BADH) & PAAG_05392.1 & 0.0 & -13 & -16 \\
\hline & $\beta$ glucosidase (BGLU) & PAAG_04545.1 & 0.0 & +1 & \\
\hline & Cysteine desulfurase (NFS1) & PAAG_05850.1 & $2 e-122$ & +4 & -7 \\
\hline & Trehalose phosphatase (TPS1) & PAAG_06703.1 & $1 e-165$ & +20 & \\
\hline \multirow[t]{3}{*}{ Fatty acid metabolism } & C-5 sterol desaturase (ERG 3) & PAAG_03651.1 & $1 e-166$ & -4 & \\
\hline & $\begin{array}{l}\text { NADP-dependent leukotriene B4 12- } \\
\text { hydroxydrogenase }\left(\text { (LTB }_{4} \mathrm{DH}\right)\end{array}$ & PAAG_05416.1 & $5 e-179$ & +1 & \\
\hline & Fatty acid elongase (GNS1/SUR4) & PAAG_08553.1 & 0.0 & +2 & \\
\hline Polysaccharide biosynthesis & Glutamine synthetase (GLN1) & PAAG_07003.1 & 0.0 & +11 & +1 \\
\hline \multicolumn{6}{|l|}{ Energy } \\
\hline Fatty acid $\beta$-oxidation & Acyl-CoA dehydrogenase (ACAD) & PAAG_03490.1 & $2 \mathrm{e}-85$ & +1 & \\
\hline Energy generation & $\begin{array}{l}\text { Glucose methanol choline oxidorreductase } \\
\text { (GMCO) }\end{array}$ & PAAG_08146.1 & 0.0 & & +3 \\
\hline \multirow[t]{6}{*}{ Morphology } & $\beta$ glucan synthesis associated protein (KRE6) & PAAG_00091.1 & $2 e-36$ & & +3 \\
\hline & a 1,6 mannosyltransferase $(\mathbf{O C H} \mathbf{1})$ & PAAG_01658.1 & 0.0 & +5 & \\
\hline & Arp 2/3 complex subunit Arc16 & PAAG_03624.1 & 0.0 & & +12 \\
\hline & Cell morphology protein (PAL1) & PAAG_02031.1 & 0.0 & +1 & \\
\hline & Integral membrane protein (MPV17/PMP22) & PAAG_02868.1 & $4 e-87$ & -6 & \\
\hline & GYF domain protein & PAAG_00627.1 & 0.0 & +5 & \\
\hline \multirow[t]{11}{*}{ Transcription } & $\mathrm{C}_{2} \mathrm{H}_{2}$ transcription factor (SEB1) & PAAG_03287.1 & 0.0 & +2 & \\
\hline & C6 transcription factor (CTF1B) & PAAG_01359.1 & 0.0 & -15 & +54 \\
\hline & Fork head box protein D1 (FOXD1) & PAAG_07388.1 & $4 \mathrm{e}-40$ & +1 & \\
\hline & GATA type sexual (NSDD) & PAAG_05818.1 & $3 e-127$ & +22 & -4 \\
\hline & Histone deacetylase (RPD3) & PAAG_06742.1 & 0.0 & +12 & \\
\hline & RING finger protein (RNF) & PAAG_06129.1 & 0.0 & -3 & -15 \\
\hline & Transcription factor (ATF1) & PAAG_01945.1 & $5 e-169$ & +1 & \\
\hline & Transcription factor fungi & PAAG_02049.1 & 0.0 & & +65 \\
\hline & Protein RNP domain & PAAG_03136.1 & $6 e-98$ & +2 & \\
\hline & Transcription factor prr1(HSF1) & PAAG_05064.1 & $6 e-89$ & +1 & \\
\hline & Transcription factor (STEA) & PAAG_00406.1 & 0.0 & +18 & \\
\hline \multirow[t]{2}{*}{ Signal transducer } & $\begin{array}{l}\text { Guanine nucleotide binding protein alpha-1 } \\
\text { subunit (GPA2) }\end{array}$ & PAAG_04436.1 & $5 e-178$ & -23 & \\
\hline & Protein with PYP-likesensor domain (PAS) & PAAG_06301.1 & 0.0 & +10 & -44 \\
\hline Protein fate & Proteasome component (PRE6) & PAAG_07802.1 & $7 e-70$ & & +3 \\
\hline \multirow[t]{2}{*}{ Protein synthesis } & Elongation factor 1-gamma 1 (eEF-1) & PAAG_03556.1 & 0.0 & & -1 \\
\hline & ATP-dependent RNA helicase (elF-4A) & PAAG_00689.1 & 0.0 & +2 & -9 \\
\hline \multirow[t]{2}{*}{$\begin{array}{l}\text { Cellular transport, transport } \\
\text { facilities and transport routes }\end{array}$} & $\begin{array}{l}\text { Calcium-transporting ATPase sarcoplasmic/ } \\
\text { endoplamic reticulum type (PMR1) }\end{array}$ & PAAG_00774.1 & 0.0 & +1 & \\
\hline & Ferric-chelate reductase (FRE) & PAAG_05370.1 & $7 e-107$ & & +2 \\
\hline
\end{tabular}


Table 1 Annotated ESTs up and down regulated genes of Paracoccidioides yeast cells treated with OenB by 90 and 180 min (Continued)

\begin{tabular}{|c|c|c|c|c|c|}
\hline & $\begin{array}{l}\text { Succinate/fumarate mitochondrial transporter } \\
\text { (SFC1) }\end{array}$ & PAAG_06563.1 & 0.0 & -4 & \\
\hline & Membrane biogenesis protein (YOP1) & PAAG_00481.1 & $7 e-143$ & & +1 \\
\hline & Major facilitator superfamily transporter (MFS) & PAAG_01353.1 & 0.0 & -27 & -22 \\
\hline & $\begin{array}{l}\text { Bodown } 198 \text { - Major facilitador superfamily } \\
\text { transporter }\end{array}$ & PAAG_06077.1 & $3 e-124$ & -4 & \\
\hline \multirow[t]{3}{*}{ Cell cycle and DNA processing } & Ribonuclease reductase large subunit (RNR1) & PAAG_02210.1 & $5 e-175$ & +1 & \\
\hline & Arginine N-methyltransferase - SKB1 (PRMT5) & PAAG_02402.1 & 0.0 & +52 & \\
\hline & SH3 domain-containing protein (CYK3) & PAAG_02301.1 & 0.0 & +2 & \\
\hline \multicolumn{6}{|l|}{ Cell rescue, defense and virulence } \\
\hline \multirow[t]{2}{*}{ Stress Response } & Phosphatase regulatory subunit (GAC1) & PAAG_00128.1 & 0.0 & +10 & \\
\hline & Heat shock protein (HSP70) & PAAG_08003.1 & $1 e-74$ & -1 & \\
\hline Virulence factor & Pathogenesis associated protein (CAP20) & PAAG_06538.1 & 0.0 & & -21 \\
\hline \multirow[t]{3}{*}{ Functional unclassified proteins } & Uncharacterized protein family UPF0121 & PAAG_00184.1 & $9 e-94$ & & +4 \\
\hline & Pleckstrin Homology $(\mathrm{PH})$ domain & PAAG_03092.1 & 0.0 & +11 & \\
\hline & DUF 1688 domain protein & PAAG_04190.1 & 0.0 & +154 & \\
\hline \multirow[t]{25}{*}{ Unclassified proteins } & Conserved hypothetical protein & PAAG_06834.1 & 0.0 & +25 & \\
\hline & Conserved hypothetical protein & PAAG_07365.1 & 0.0 & +34 & \\
\hline & Conserved hypothetical protein & PAAG_05009.1 & 0.0 & +10 & -3 \\
\hline & Conserved hypothetical protein & PAAG_07364.1 & 2e-139 & +4 & +2 \\
\hline & Conserved hypothetical protein & PAAG_04732.1 & 0.0 & +7 & \\
\hline & Conserved hypothetical protein & PAAG_03559.1 & 0.0 & +2 & \\
\hline & Conserved hypothetical protein & PAAG_02868.1 & $4 e-87$ & +11 & \\
\hline & Conserved hypothetical protein & PAAG_01170.1 & $9 e-122$ & +1 & \\
\hline & Conserved hypothetical protein & PAAG_04190.1 & 0.0 & -1 & \\
\hline & Conserved hypothetical protein & PAAG_06925.1 & 0.0 & & +1 \\
\hline & Conserved hypothetical protein & PAAG_08832.1 & $3 e-143$ & & +5 \\
\hline & Conserved hypothetical protein & PAAG_07770.1 & $3 e-143$ & & +1 \\
\hline & Conserved hypothetical protein & PAAG_03654.1 & $2 e-70$ & & +63 \\
\hline & Conserved hypothetical protein & PAAG_00520.1 & $1 e-7$ & & +1 \\
\hline & Hypothetical protein & PAAG_07199.1 & $7 e-126$ & & +7 \\
\hline & Hypothetical protein & PAAG_03580.1 & 0.0 & +6 & \\
\hline & Hypothetical protein & PAAG_04733.1 & 0.0 & +3 & \\
\hline & Hypothetical protein & PAAG_06820.1 & 0.0 & +1 & \\
\hline & Hypothetical protein & PAAG_08066.1 & $7 e-71$ & & +27 \\
\hline & Hypothetical protein & PAAG_05558.1 & $7 e-76$ & & +1 \\
\hline & Hypothetical protein & PAAG_03580.1 & 0.0 & & -1 \\
\hline & Hypothetical protein & PAAG_03099.1 & $2 e-151$ & & +45 \\
\hline & Hypothetical protein & PAAG_06251.1 & 0.0 & -3 & \\
\hline & Hypothetical protein & PAAG_01169.1 & 0.0 & +1 & \\
\hline & Hypothetical protein & PAAG_08809.1 & 0.0 & & +1 \\
\hline
\end{tabular}

\footnotetext{
${ }^{a}$ Accession number at Broad (http://www.broadinstitute.org).
} 
genes after exposure to the compound (Additional file 1: Figure S1). The groups with the highest percentage of up-regulated genes were the unclassified proteins (30\%), transcription (23\%), functional unclassified proteins (22\%), metabolism (10\%), cell cycle and DNA processing (7\%) and morphology (4\%). The highest percentage of down-regulated genes was grouped in the signal transducer (27\%), cellular transport, transport facilities and transport routes $(22 \%)$, transcription $(15 \%)$, cell rescue, defense and virulence (14\%), metabolism (12\%), unclassified proteins $(4 \%)$, protein synthesis $(4 \%)$ and morphology (2\%) groups.

The distribution of differentially expressed genes in the different functional categories and biological processes was evaluated (Table 1; Figure 1). The analysis demonstrated that most of the genes that were downregulated after 90 min participate in cellular processes related to transport, followed by signal transducers and those involved in transcription and metabolism. On the other hand, the up-regulated genes were mostly found to be functionally unclassified proteins, followed by unclassified proteins, and those involved in cell cycle and DNA processing and metabolism. After $180 \mathrm{~min}$ treatment, most of the down-regulated genes were also involved in signal transduction, metabolism and cellular transport. The up-regulated genes were unclassified proteins or those involved in transcription and morphology determination. The percentage of occurrence of each gene in the libraries was indicated in the Additional file 2: Table S1.

The OenB treatment resulted in up-and down-regulated genes involved in different biological processes (Table 1; Figure 2). We analyzed the occurrence of the transcripts by determining the number of ESTs found in each transcript. The highest occurrence of up-regulated ESTs after $90 \mathrm{~min}$ of OenB treatment were as follows: DUF 1688 domain protein (154 ESTs), arginine N-methyltransferaseSKB1 (PRMT5) (52 ESTs), GATA-type sexual (NSDD) (22 ESTs), trehalose phosphatase (TPS1) (20 ESTs), histone deacetylase (RPD3) (12 ESTs), glutamine synthetase (GLN1) (11 ESTs), phosphatase regulatory subunit (GAC1) (10 ESTs) and protein with a PYP-like sensor domain (PAS) (10 ESTs). For down-regulated ESTs, the highest expression transcripts were the following: major facilitator superfamily transporter (MFS) (27 ESTs), guanine nucleotide binding protein alpha-1 subunit (GPA2) (23 ESTs) and C6 transcription factor (CTF1B) (15 ESTs).

Likewise, we analyzed the up-and down-regulated genes resulting from $180 \mathrm{~min}$ of OenB treatment and

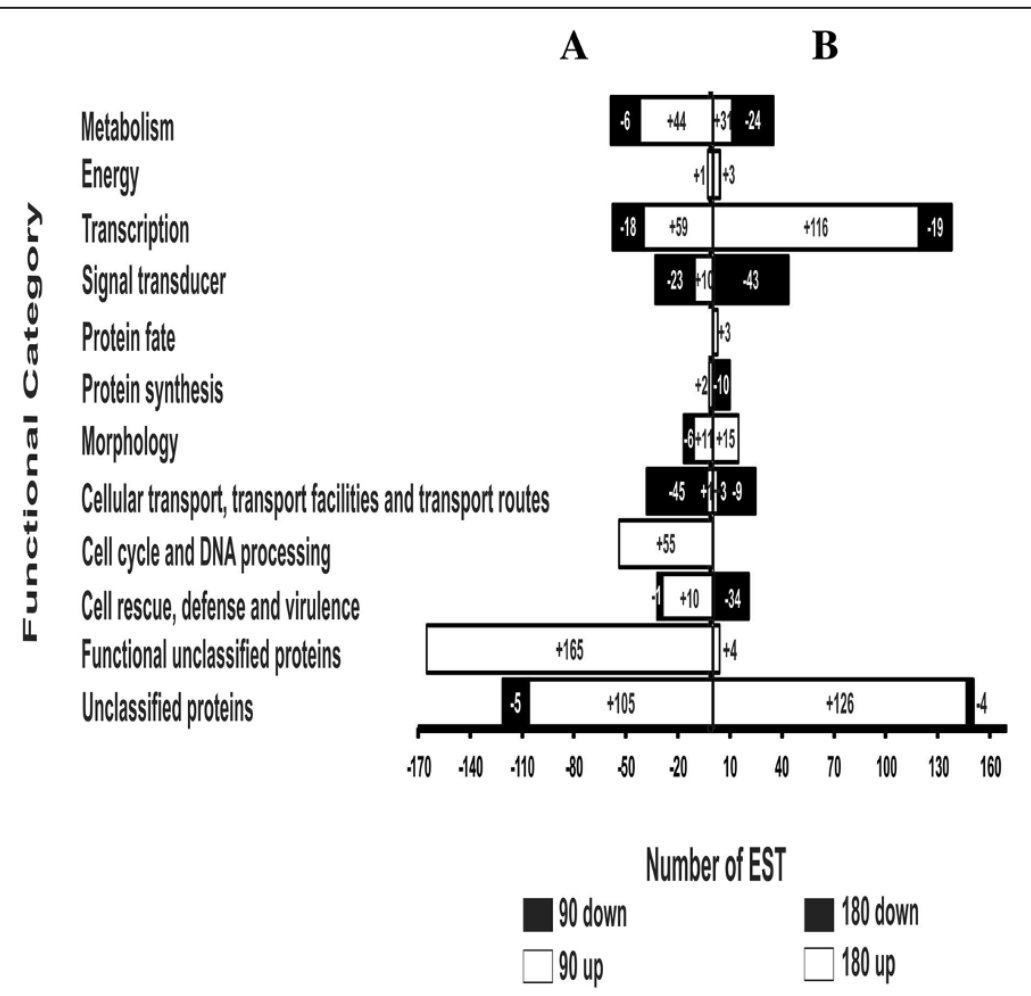

Figure 1 Functional classification of differentially expressed genes in biological functional groups. (A) Down- and up-regulated genes obtained from cDNAs synthesized from RNAs of Paracoccidioides cells exposure to OenB for 90 min and (B) 180 min. Functional classification was based on Blast X homology of each EST against the GenBank non-redundant database and the nucleotide database from the Paracoccidioides structural genome at a significant homology cut-off $\leq 10^{-5}$ and a MIPS functional annotation scheme. Each functional class is represented as a segment and expressed as the total number of ESTs in each library. 


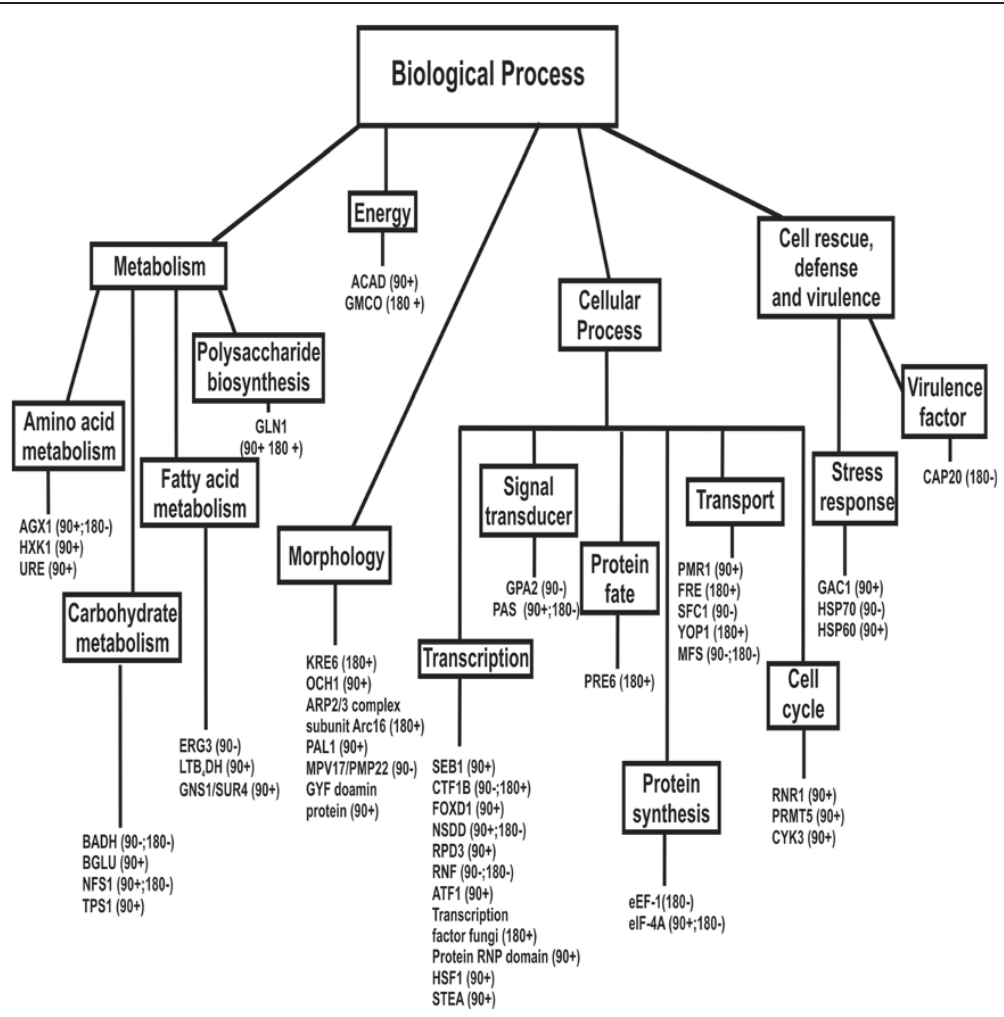

Figure 2 Distribution of genes responding to OenB in Paracoccidioides. The most evident up- and down-regulated genes are shown. Data were organized into various biological processes using Functional Categories MIPS and GO tools. A positive signal indicates increased, and negative values indicate reduced transcript levels. A complete list of all significant genes can be found in Table 1.

noted genes that might be involved in different biological process (Table 1; Figure 2). The highest transcription expression of transcripts after 180 min of treatment were the following for up-regulated ESTs: transcription factor fungi (65 ESTs), glutamine synthetase (GLN1) (1 EST) and arp 2/3 complex subunit Arc16 (12 ESTs). For down-regulated ESTs, the highest transcript expression of transcripts were the following: protein with PYP-like sensor domain (PAS) (44 ESTs), pathogenesis associated protein (CAP20) (21 ESTs), betaine aldehyde dehydrogenase (BADH) (13 ESTs) and RING finger protein (RNF) (15 ESTs). The most evident up- and downregulated genes are shown in the Figure 2.

\section{Quantitative real-time PCR (qRT-PCR)}

RDA is a methodology that enriches for differentially expressed sequences within transcriptional profiles and specifically permits the detection of transcripts that are differentially represented even at low levels of expression, such as transcription factors and other regulatory genes. While representative in general terms, further confirmation of identified sequences is indicated, as in any high throughput approach, and qRT-PCR is a method of choice for this confirmation process.
Consequently, we designed gene-specific primers for a set of the ESTs obtained from the RDA libraries of Paracoccidioides yeast cells treated with OenB for 90 and $180 \mathrm{~min}$. In this set, we evaluated genes represented in the libraries by one or more ESTs and to genes from a different functional GO category. For all seven selected genes, we obtained primer sequences that amplified specific products. Some genes selected for confirmation by qRT-PCR were also assessed after $24 \mathrm{~h}$ of infection of macrophages by Paracoccidioides. These sequences are shown in Table 2.

The expression levels of the up- and down-regulated genes from the library of yeast treated for $90 \mathrm{~min}$ were confirmed as significantly higher for PAL1 and GLN1 and significantly lower for the MFS and ERG3 genes, compared to the controls, which was in accordance with the results from the RDA methodology. All four genes from the library of yeast treatment for $180 \mathrm{~min}$ also corroborated the results from the RDA methodology because the levels of expression were significantly higher for GLN1 and KRE6 and significantly lower for MFS and CAP20 genes (Figure 3A).

The FKS1 gene was analyzed because we found in our previous work that the gene was repressed in the presence of OenB [19]. Here, the decreased level of FKS1 
Table 2 Oligonucleotide primers used in RDA assay and qRT-PCR

\begin{tabular}{|c|c|c|c|}
\hline Sequence name & Forward primer $\left(5^{\prime}-3^{\prime}\right)$ & Reverse primer $\left(5^{\prime}-3^{\prime}\right)$ & Reaction \\
\hline CDNA & AGCAGTGGTATCAACGACAGAGTACGCGGG & & Synthesis of the first-strand for RDA \\
\hline CDS & AAGCAGTGGTATCAACGCAGAGTACT(30)N1N & & Synthesis of the first-strand for RDA \\
\hline PCRII & AAGCAGTGGTATCAACGCAGAGT & & Synthesis of the first-strand for RDA \\
\hline JBam12, 24 & GATCCGTTCATG & ACCGACGTCGACTATCCATGAACG & Adapter 1 (RDA) \\
\hline NBam12,24 & GATCCTCCCTCG & AGGCAACTGTGCTATCCGAGGGAG & Adapter 2 (RDA) \\
\hline T7 & GTAATACGACTCACTATAGGGC & & Sequencing \\
\hline Oligo $(d T)_{15}$ & AAGCAGTGGTATCAACGCAGAGTACT(30)N1N3' & & Synthesis of the first-strand for qRT-PCR \\
\hline CAP20 & CCTTCACGAACTCGCCACTAT & TCGCTGCTTAGGGAGTCTGC & qRT-PCR \\
\hline FKS1 & GACAACAGAGGGTATAATGGG & GCCATATTGATAGCCTGCAGC & qRT-PCR \\
\hline GLN1 & CGATCAAAAACAAAGACCCT & GGTCTGGGTACATGGCAAC & qRT-PCR \\
\hline KRE6 & GGTATATGCCTAACTTTGAATTC & GCGTAGACTTGATACTCTITTG & qRT-PCR \\
\hline GAC1 & AGTACTGCTTCTATGGATCTTC & ACTATTTCCTGGGGTCGTTG & qRT-PCR \\
\hline MFS & CTAATTATGTTCTITTGGGGTAC & GCATCGCCTATACCAACAAGA & qRT-PCR \\
\hline PAL1 & TGCTGCGGAACTCTITGA & GGGCTTATCGTCGGAGAGTC & qRT-PCR \\
\hline ERG3 & CACTTGGATCTTCGGCCTAAT & TGCATAGCCACGGACTTCGA & qRT-PCR \\
\hline
\end{tabular}

$(\mathrm{N} 1=\mathrm{A}, \mathrm{G}$ or $\mathrm{C} / \mathrm{N}=\mathrm{A}, \mathrm{C}, \mathrm{G}$ or $\mathrm{T})$.

after 90 and 180 min of treatment are in agreement with our previous data.

Previous studies using electron microscopy have demonstrated the formation of large vacuoles with almost no electron density, the presence of lysed cells, partial disruption of the cell wall and cytoplasmic organelle leakage out of OenoB-treated Paracoccidioides yeast cells [19]. Here, genes related to osmotic stress, such as RPD3, ATF1, HSF1 and GAC1 were up-regulated in Paracoccidioides yeast cells after OenB-treatment. In this way, the GAC1 gene, which responds to osmotic stress [28], was evaluated in the presence of $\mathrm{KCl}$. It is noteworthy that $\mathrm{KCl}$ was used in this study as a stressor because it is an osmotic stress inducer and we found that it acted on the cell wall of Paracoccidioides in our previous study [29]. Our results indicated that the GAC1 gene responds to osmotic stress because its expression level was increased in the presence of OenB and $\mathrm{KCl}$ (Figure 3B).

\section{Transcript levels in OenB-treated Paracoccidioides yeast cells after internalization by macrophage cells}

To investigate if the transcripts identified by RDA would also be up- or down- regulated in vivo, Paracoccidioides yeast cells were internalized by macrophage cells and the transcript levels were then quantified. J774A.1 mouse macrophage cells infected with Paracoccidioides were treated with OenB for $24 \mathrm{~h}$, and qRT-PCR analysis was carried out for the genes KRE6, GLN1, FKS and ERG3. The expression levels of genes found to be upand down-regulated in the libraries of yeast cells treated for 90 and $180 \mathrm{~min}$ were confirmed. Expression was significantly lower for ERG3 and significantly higher for KRE6 and GLN1 after $24 \mathrm{~h}$ of infection. The FKS1 gene, which was down- regulated in the presence of OenB in our previous work [19], was also dow- regulated during macrophage infection (Figure $3 \mathrm{C}$ ). The results are in agreement with those found in the RDA and qRT-PCR assays when Paracoccidioides yeast cells were treated with OenB in vitro.

\section{Cell analysis by fluorescence microscopy}

Calcofluor White (CFW) and Congo Red (CR) both stain the cell wall of fungi by binding to chitin chains [30]. CFW and CR dyes interact with various polysaccharides [31] but exhibit a particularly high affinity for chitin $[32,33]$.

To investigate the chitin level in the cell wall, Paracoccidioides $P b 01$ and $P b 18$ yeast cells were grown in liquid medium for $72 \mathrm{~h}$ with and without OenB, after which they were stained with Calcofluor White (CFW) and Congo Red (CR) and visualized by fluorescence microscopy. OenB-treated Paracoccidioides cells showed a stronger fluorescence when compared to the control, indicating increased chitin levels (Figure 4).

\section{Carbohydrate content of the cell wall}

The cell wall is divided in alkali-soluble (AS) and alkaliinsoluble (AI) fractions according to its solubility in alkaline substances. In the Paracoccidioides Pb01 yeast phase, the glucan polymer consists mainly of $1,3-\alpha$-glucan (95\%) which is present in the AS fraction, and a small amount of the 1,3- $\beta$-D-glucan (5\%), which is present in the AI fraction [34]. GlcNAc residues are also 




found in the AI fraction. Figure 5A shows a decrease in total carbohydrate content in the AI fraction after OenB-treatment; no alteration in carbohydrate content was observed in the AS fraction. 1,3- $\beta$-D-glucan content was estimated after the digestion of the AI cell wall fraction with the 1,3- $\beta$-glucanase enzyme. As shown in Figure $5 \mathrm{~B}$, there was a decrease in $1,3-\beta-\mathrm{D}$-glucan content. In addition there was an increase in GlcNAc residue content in this fraction (Figure $5 \mathrm{C}$ ), suggesting an increase in the chitin polymer concentration. 


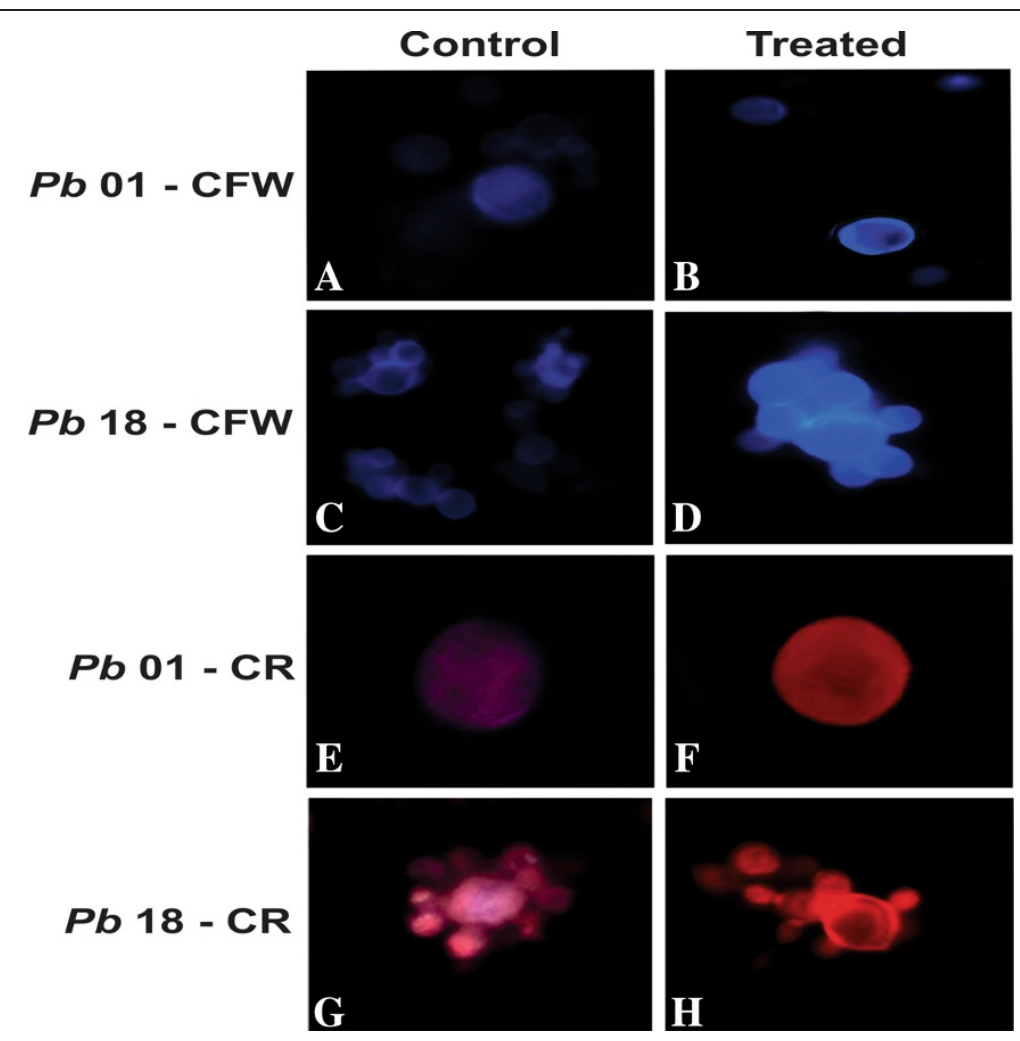

Figure 4 Fluorescence microscopy showing Paracoccidioides Pb01 and Pb18 isolates stained by CFW and CR. (A) Pb01 control stained with CFW; (B) Pb01 after treatment with OenB, stained with CFW; (C) Pb18 control stained with CFW; (D) Pb18 after treatment with OenB, stained with CFW; (E) Pb01 control stained with CR; (F) Pb01 after treatment with OenB, stained with CR; (G) Pb18 control stained with CR; (H) Pb18 after treatment with OenB, stained with CR. The cells after treatment with OenB showed intense fluorescence when stained with CFW and CR.

\section{Discussion}

The aim of this study was to identify changes in the gene expression profile of Paracoccidioides yeast cells after OenB treatment in order to investigate the adaptive cellular responses of the fungus. In the RDA libraries, genes related to metabolism, energy, morphology, transcription, transport, among others were found to be differentially expressed relative to the control.

In our previous work, were visualized several events indicative of Paracoccidioides cell wall collapse in the presence of OenB [19]. In the cDNA libraries, some genes involved in the biosynthesis of the polysaccharide cell wall (GLN1) and morphology (KRE6, OCH1 and MPV17/PMP22) were up-regulated in OenB-treated Paracoccidioides yeast cells. Although the FKS1 transcript was not found in the cDNA library, the down-regulation of the FKS1 transcript was confirmed by qRT-PCR, thus corroborating previous data [19]. The decreased amount of the 1,3- $\beta$-D-glucan polymer was confirmed here after the digestion of the cell wall.

The cell wall composition of Paracoccidioides varies biochemically depending on its phase. The cell wall of the yeast phase, found in infected tissue and in vitro culture at $36^{\circ} \mathrm{C}[35,36]$, has more chitin polymer and less $1,3-\beta$-D-glucan polymer than found in the saprophytic mycelium phase. The 1,3- $\alpha$-D-glucan polymer was only found in the yeast phase [34,37]. The polysaccharide $\alpha$ glucan is supposedly located in a more external region of the cell wall and is related to virulence [38,39]. Both $1,3-\beta$-D-glucan and chitin are linked to cell wall structural function. In addition, 1,3- $\beta$-D-glucan is an immunogenic molecule $[39,40]$.

Glutamine synthetase (GLN1) was up-regulated in OenB-treated Paracoccidioides yeast. GLN1 catalyzes the synthesis of glutamine from glutamate and ammonia [41] and contributes glutamine to the synthesis of chitin [42]. Here, the increase of chitin level was confirmed by fluorescence microscopy. In Mycobacterium bovis, GLN1 is necessary for cell wall resistance [43]. In previous studies conducted with Paracoccidioides, the increase in GLN1 transcript was related to chitin deposition in response to change in external osmolarity faced by the fungus [44]. The increase in chitin synthase transcripts and chitin synthesis in C. albicans and A. fumigatus after treatment with antifungal agents has been shown to be an important compensatory response to cell wall stress $[45,46]$.

The increase in chitin synthesis has been shown to be an important compensatory response to cell wall stress. 

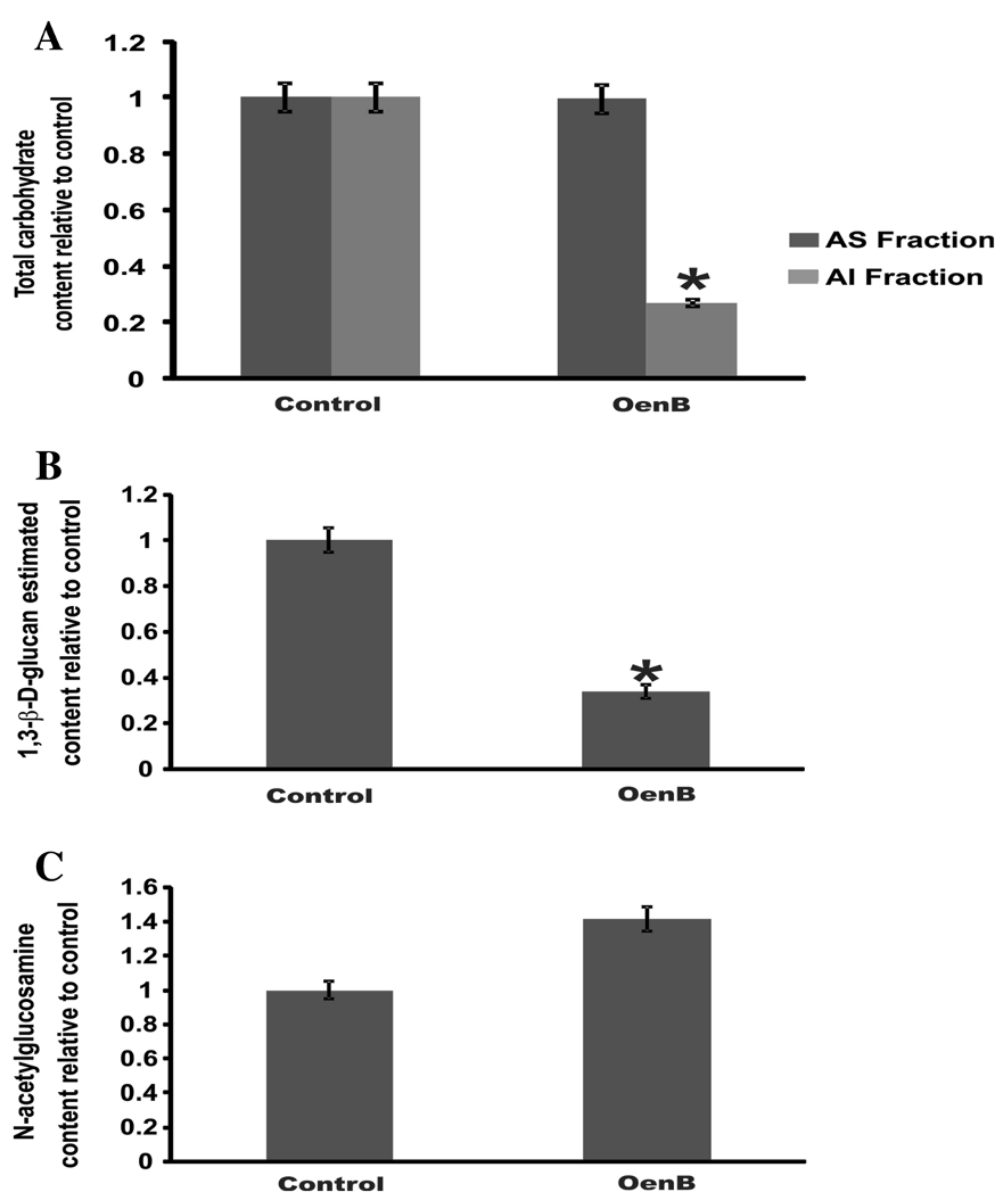

Figure 5 Carbohydrate content in the cell wall of Paracoccidioides yeast cells exposed to OenB. The cell walls of Paracoccidioides that were either untreated (control) or treated with OenB were isolated. The alkali-soluble (AS) and alkali-insoluble (Al) fractions were separated. (A) Total amount of carbohydrates was measured in the AS and Al fractions. (B) The amount of 1,3- $\beta$-D-glucan polymer was estimated in the Al fraction. (C) The amount of $\mathrm{N}$-acetylglucosamine (GlcNAc) residue was measured in the total cell wall fraction. All data were normalized relative to the control. Three independent experiments were performed. * Significantly increased amount $(p \leq 0.05)$.

In $C$. albicans, increased chitin synthase gene expression has been observed after treatment with micafungin, implying that the induction of chitin synthesis might contribute to cell survival when the cell wall is damaged [45]. In addition the transcription levels of $c h s A$ and $\operatorname{chs} C$, two chitin synthases, were increased in A. fumigatus after treatment with echinocandin [46].

$\beta$-glucan synthesis associated protein (KRE6) was also up-regulated in Paracoccidioides after $180 \mathrm{~min}$ of OenBtreatment. KRE and KRE-related genes are required for the synthesis of cell wall 1,6- $\beta$-glucan in S. cerevisiae [47]. In addition, the disruption of kre6 reduces 1,6- $\beta$-glucan levels [48]. The 1,6- $\alpha$-glucan and the genes involved in its synthesis are critical for maintaining the growth, morphology and cell wall integrity of C. neoformans [49].

The 1,6- $\alpha$-mannosyltransferase $(\mathrm{OCH} 1)$ gene was upregulated in Paracoccidioides after $90 \mathrm{~min}$ of OenBtreatment. $\mathrm{OCH} 1$ has many functions, including its inclusion in protein structures, its involvement in the maintenance and morphology of the cell wall and cell membrane, the synthesis of the extracellular matrix, storage of nutrients, and can also function as a ligand for cell-cell interaction [50]. In Neurospora crassa, $\mathrm{OCH} 1$ is required for the incorporation of cell wall proteins into the cell wall matrix [51]. In yeast including $S$. cerevisiae, C. albicans and Candida glabrata, mannan polymer (mannoprotein) provides the strength and shape for the resistance to environmental stress [52]. $\mathrm{OCH} 1$ transcription, which is regulated by the transcription factors ATF1, HSF1, and RPD3 cited above [53], may synthesize mannoproteins to be deposited in the cell wall [54].

Mannoproteins, chitin and $\beta-1,6$-glucan are required to maintain the cell wall and are therefore essential to cell viability [55]. Here, several genes involved in cell wall biosynthesis were up-regulated. The fungal cell wall is an important organelle that protects the cell from various environmental stressors. It is a dynamic structure that 
interacts with the environment and is modified to accommodate growth, cell division, and development [56,57]. In our previous work using electronic microscopy, several hallmark changes were found, including squashing, the presence of vacuoles with low electron density, a rough surface, cell wall rupture and cell membrane recess [19].

Others genes related to cellular morphology were also shown to be differentially regulated, such as ERG3 and MPV17/PMP22. The C-5 sterol desaturase (ERG3) gene was down-regulated in Paracoccidioides yeast treated with OenB for 90 min. ERG3 acts in the ergosterol biosynthesis, which is one of the most important components of fungal membrane [58]. It maintains the integrity and fluidity of the cell membrane [59] and consequently may affect the morphology [60], virulence [61] and resistance of fungal pathogens [62]; its biosynthetic pathway is essential for fungal growth [63]. The presence of cell membrane recess and folding to the inner cytoplasm initiating the formation of vacuoles was observed in OenB-treated Paracoccidioides yeast cells [19].

The transmembrane protein (MPV17/PMP22) was down-regulated in Paracoccidioides after $90 \mathrm{~min}$ of OenB treatment. In S. cerevisiae, Sym1, which is homologous to MPV17, is involved in the structural and functional stability of the inner mitochondrial membrane, thus controlling crucial mechanisms related to this compartment, including the activity of respiratory chain complexes, the mitochondrial morphology and the maintenance and integrity of nucleotide structures [64]. The leakage of cytoplasmic organelles was observed in Paracoccidioides yeast cells that were treated with OenB [19].

The major facilitator superfamily transporter (MFS) gene was down-regulated in OenB-treated Paracoccidioides yeast. The MFS transporters include important families of membrane protein transporters which utilize diverse substrates and catalyze different modes of transport [65]. In $S$. cerevisiae and Candida spp., the up-regulation of multidrug transporter genes belonging either to the $\mathrm{ABC}$ family or to the MFS family is frequently observed in cells exposed to drugs and leads to the phenomenon of MDR (multidrug resistance) $[65,66]$. However, there are compounds, such as FK506, enniatins, milbemycins, synthetic D-octapeptides, cyclosporine, isonitrile, disulfiram, ibuprofen, and unnarmicins, that inhibit fungal $A B C$ transporters $[67,68]$. Such inhibitors or chemo sensitizers probably act directly by affecting substrate binding and transport mediated by MDR efflux proteins [69]. In S. cerevisiae, the natural product curcumin competitively inhibitis R6G (rhodamine 6G), an MFS transporter [69]. Clorgyline, a drug previously used as an antidepressant, was found to enhance the antifungal effect of fluconazole against azoleresistant yeast species, including $C$. albicans and $C$. glabrata strains, via the inhibition of $\mathrm{ABC}$ and MFS fungal efflux pumps [70].
Although echinocandin, an antifungal acting at the fungal cell wall, provides fungicidal activity against Candida spp., it is only fungistatic against Aspergillus spp. [71]. In Paracoccidioides, micafungin and echinocandin are more active against mycelia than against the yeast phase [72], although caspofungin can partially inhibit yeast phase growth, in different Paracoccidioides isolates [73]. In addition, it is important to develop antifungals that are active against the yeast phase because that is the pathogenic phase [74]. Our data indicate that OenB interferes with the Paracoccidioides cell wall. Because this structure is found in the fungus but not in human beings, it could be nontoxic to humans and may be an interesting antifungal prototype candidate.

\section{Conclusions}

Our results indicate that the exposure of Paracoccidioides to OenB results in a complex altered gene expression profile. Some of the changes might represent specific adaptive responses to this compound because genes involved in the cell wall were differentially expressed, and polymer and image analysis fluorescence microscopy corroborated with transcriptome data.

\section{Methods}

\section{Plant material}

E. uniflora leaves were collected in Anápolis, Goiás, Brazil and the sample of specimens were deposited at the Herbarium of the Universidade Federal de Goiás UFG, with code number UFG 25477. Access authorization and sample remittance of component of the genetic property is $n^{\circ} 005 / 2007$.

\section{Extraction, isolation and identification of OenB from $E$. uniflora}

The extraction, isolation and identification of OenB were realized as described previously [19]. Briefly, powdered leaves of E. uniflora $(1.0 \mathrm{~kg}$ ) were extracted with $50 \%$ aqueous acetone. The dry crude extract (174.27 g) was obtained by concentration in vacuum followed by freeze-drying and a part (150 g) was extracted with ethyl acetate. The aqueous layer was lyophilized to yield a $122.14 \mathrm{~g}$ fraction which was dissolved in methanol $(\mathrm{MeOH})$ to separate the soluble $(81.76 \mathrm{~g})$ and the insoluble (39.22 g) methanolic fractions. The insoluble fraction $(10 \mathrm{~g})$ was submitted to separation and purification by Column Cromatography on Diaion HP-20, followed by $\mathrm{CC}$ on Sephadex $\mathrm{LH}-20$, eluted with a water-MeOH gradient to obtain the IM-7 sub-fraction $(791.5 \mathrm{mg})$. From this, OenB (62.4 mg) was isolated (purity of 96\%) on a preparative HPLC system. The chromatographic system consisted of LC-10ADvp pumps (Shimadzu Corporation, Tokyo, Japan) connected to an SPD-10AVvp ultraviolet photodiode array detector. Chromatographic 
separations were performed using a LiChrospher RP-18 column (Shimadzu Corporation). The compounds were eluted using acetonitrile (A) $0.01 \mathrm{M} \mathrm{H}_{3} \mathrm{PO}_{4}: 0.01 \mathrm{M}$ $\mathrm{KH}_{2} \mathrm{PO}_{4}$ (B) (gradient $8 \% \mathrm{~A}$ in $\mathrm{B}$ to $18 \%$ ) for $20 \mathrm{~min}$ at a flow rate of $1.0 \mathrm{~mL} / \mathrm{min}$.

Paracoccidioides culture and determination of cell viability Paracoccidioides (ATCC MYA 826) has been studied extensively in our laboratory [75-78]. Paracoccidioides Pb01 yeast cells were sub-cultured every seven days on solid Fava-Netto's medium $(1.0 \% \mathrm{w} / \mathrm{v}$ peptone, $0.5 \% \mathrm{w} / \mathrm{v}$ yeast extract, $0.3 \% \mathrm{w} / \mathrm{v}$ protease peptone, $0.5 \%$ beef extract, $0.5 \% \mathrm{w} / \mathrm{v} \mathrm{NaCl}, 4 \% \mathrm{w} / \mathrm{v}$ glucose and $1.4 \% \mathrm{w} / \mathrm{v}$ agar, $\mathrm{pH}$ 7.2) [79] at $36^{\circ} \mathrm{C}$ and used throughout this study. For viability experiments, yeast cells were grown in the presence or absence of OenB for specific time intervals and were kept in $\mathrm{MMcM}$ chemically defined medium [80] at $36^{\circ} \mathrm{C}$. The cellular viability was determined by the trypan blue method [81]. The quantity of OenB used was $500 \mu \mathrm{g} / \mathrm{mL}(0.32 \mathrm{M})$, which corresponds to minimal inhibitory concentration (MIC) [19]. In brief, cells were incubated with the dye solution ( $0.1 \%$ trypan blue stain) for $5 \mathrm{~min}$ at room temperature, and viability was assessed by counting viable and unviable cells in a Neubauer chamber.

\section{J774 A.1 mouse macrophage cell culture and infection with Paracoccidioides}

The J774 A.1 mouse macrophage cells were purchased from a cell bank in Rio de Janeiro (Rio de Janeiro, Brazil) and were maintained in cell culture bottles in an atmosphere of $5 \%$ carbon dioxide at $37^{\circ} \mathrm{C}$ in RPMI 1640 medium supplemented with $10 \%$ heat-inactivated fetal bovine serum (Vitrocell/Embriolife, Campinas, SP, Brazil), 10\% amino acid solution (Sigma Biochemical, St. Louis, MO, USA) and $0.2 \%$ of gentamicin solution (Sigma Biochemical).

The macrophages were quantified by counting them in a Neubauer chamber, after which they were plated at a density of $10^{6}$ cells per well on glass cover slips in 24well culture plates. The macrophages were then infected with $2.5 \times 10^{6}$ Paracoccidioides Pb01 yeast cells, also determined by counting Neubauer chamber. The cells were co-cultured for $24 \mathrm{~h}$ in the presence of $0.32 \mathrm{M}$ OenB at $36^{\circ} \mathrm{C}$ and $5 \% \mathrm{CO}_{2}$ to allow the internalization of the fungus. After this period, the supernatants were then aspirated, and the layer was observed microscopically, to visualize the fungal cells that had been internalized by the macrophages. The number of viable fungi cocultivated with the macrophages was determined by quantifying the number of colony forming units (CFUs). Then, the monolayer was gently washed with $1 \times$ PBS to remove any non-adherent/internalized yeast cells, and the total RNA was isolated.

\section{RNA isolation and CDNA synthesis}

Paracoccidioides Pb01 yeast cells were cultured in MMcM medium only or in the same medium with $0.32 \mathrm{M}$ OenB for 90 and $180 \mathrm{~min}$. For RNA isolation, cells were collected by centrifugation and the RNAs of driver and tester cultures were extracted with Trizol (Invitrogen, Carlsbad, CA, USA) according to the manufacturer's instructions. RNA quality was assessed by determining the $A_{260 n m} / A_{280 n m}$ ratio and by the visualization of RNAs by $1.5 \%$ agarose gel electrophoresis. The RNAs were used to construct subtracted cDNA libraries. The first-strand cDNAs were synthesized from $1 \mu \mathrm{g}$ of total RNAs using reverse transcriptase (RT Superscript III, Invitrogen) and were then used as a template from which to synthesize the second-strand using a SMART PCR cDNA synthesis kit (Clontech Laboratories, Palo Alto, CA, USA).

\section{RDA method}

The RDA technique was used to generate libraries [27]. RDA is a PCR-based subtractive enrichment procedure. Originally developed for the identification of differences between complex genomes [82], this technique was adapted to enable the isolation of genes with an altered expression for comparison among various cell samples (cDNA RDA) [83]. The procedure relies on the generation of cDNA fragments from two different mRNA populations digested with restriction endonucleases, followed by adapter ligation and PCR amplification. The generated fragments are then subjected to successive rounds of subtractive hybridization and selective PCR amplification, to enrich the fragments of cDNA that are more abundant in one population [27].

The double-stranded cDNAs $(1 \mu \mathrm{g})$ were then digested with the Sau3AI restriction enzyme (Amersham Biosciences, Little Chalfont, Uppsala, Sweden), and the digestion products were linked to adapter primers and PCR-amplified to generate cDNAs representative of the driver and tester libraries. Two successive rounds of PCR amplification employing different adapters (J-Bam and N-Bam, Table 2) were performed to enrich the differentially expressed sequences. In the first round, the tester/driver ratio of 1:10 was used for the hybridization, whereas in the second round the tester/driver ratio was set at a higher stringency of 1:100. Before each round of hybridization, the cDNAs were purified using a GFX PCR purification kit (GE Healthcare UK, Little Chalfont, Buckinghamshire, England). In the RDA method, cDNA from yeast cells cultured in MMcM broth medium containing $0.32 \mathrm{M}$ of OenB for 90 and $180 \mathrm{~min}$ was used as the tester population and was hybridized to cDNA from yeast cells cultured in MMcM broth medium only for 90 and $180 \mathrm{~min}$ as the driver population, and vice-versa. This resulted in four differential expression 
libraries, two for up-regulated and two for downregulated transcripts. The adapters used for the subtractive hybridizations are listed in Table 2 .

The cDNAs from these libraries were cloned into pGEM-T Easy vector (Promega, Madison, WI, USA), which was used to transform Escherichia coli XL1 Blue electro competent cells. The positive colonies were picked and grown in deep-well plates. The plasmid DNA was purified by a miniprep protocol and was used as the template in the standard fluorescence labeling dyeterminator protocols with a T7 flanking vector primer. The reaction products were loaded onto a MegaBACE 1000 DNA sequencing system (GE Healthcare) for automated sequence analysis.

\section{Bioinformatics analysis}

The reading quality was checked by the Phred program module [84], and were chose to analyze the sequences with at least 50 nucleotides and a quality grater or equal to 20. Subsequently, vector sequences were trimmed using the Crossmatch program [85]. Readings that had passed the quality check were next submitted to a CAP3 program [86] to obtain the final set of contigs and singlet sequences. All these tools were integrated in a specific pipeline [87]. The sequences obtained were dynamically translated and compared against the GenBank [88] non-redundant (nr) database from NCBI using the Blast X program [89] and the nucleotide database from the Paracoccidioides structural genome [90]. The database sequence matches were considered significant at $e$-values $\leq 10^{-5}$.

Sequence analysis and the annotation pipeline were set up using the Blast2GO program [91] that joints in one GO application based on a similarity search with statistical analysis and highlighted visualization on a directed acyclic graph [92]. The Blast2GO annotation algorithm already took multiple parameters into account such as sequence similarity, blast HSP (highest scoring pair) length and e-values, the GO hierarchical structure and GO term evidence codes [92,93]. The sequences were grouped into functional categories according to the classification of the MIPS functional catalog [94].

Graphs were plotted to demonstrate the statistically enriched GO functions with up- or down-regulated genes, respectively, for the times of exposure to the compound (Additional file 1: Figure S1). The percentage of occurrence of each gene in relation to the total number of genes from the libraries was calculated and shown Additional file 2: Table S1.

\section{Quantitative real-time PCR}

For the qRT-PCR analysis of a subset of genes indicated as differentially expressed, gene-specific primers were designed using the software Primer Express (Applied
Biosystems, Foster City, CA, USA). The predicted product lengths varied between $100 \mathrm{bp}$ and $200 \mathrm{bp}$. The reference $\alpha$-tubulin gene was used for normalization. Total RNA was extracted from control and OenBtreated yeast using Trizol reagent. The total RNA was also extracted from control and OenB-treated cells after infection with Paracoccidioides.

First strand cDNA was produced using a SuperScript III (Invitrogen) and oligo $(\mathrm{dT})_{15}$ primer. All qRT-PCR assays were run using a SYBR Green (Applied Biosystems) protocol in a StepOnePlus ${ }^{\mathrm{TM}}$ Real-Time PCR system (Applied Biosystems). The amplification protocol was 40 cycles of $95^{\circ} \mathrm{C}$ for $15 \mathrm{~s} ; 60^{\circ} \mathrm{C}$ for $1 \mathrm{~min}$. The qRT-PCR assays were performed in triplicate.

The SYBR Green PCR master mix (Applied Biosystems) was used as the reaction mixture, and 10 pmol of each specific primer and $40 \mathrm{ng}$ of template cDNA were added to a final volume of $25 \mu \mathrm{L}$. A melting curve analysis was performed to confirm a single PCR product. The data were normalized against $\alpha$-tubulin in each set of qRT-PCR experiments. The relative expression levels of the genes of interest were calculated using the standard curve method for relative quantification [95]. The Student's $t$ test was used for statistical comparisons and $P$ values $\leq 0.05$ were considered statistically significant. The specific sense and antisense primers are listed in Table 2.

\section{Dosage of cell wall polymers}

To measure the amount of total carbohydrates, Paracoccidioides $\mathrm{Pb} 01$ yeast cells were grown in liquid Fava-Netto's medium at $36^{\circ} \mathrm{C}$ for $72 \mathrm{~h}$ with or without OenB. The cell wall polymers were obtained as previously described [29]. In brief, yeast cells were collected and washed with acetone, ethyl alcohol and ether. Then, the cells were suspended in $50 \mathrm{mM}$ TrisHCl pH 7.5 and disrupted with glass beads. Cell walls were separated from the cytosolic fraction by centrifugation. The alkalisoluble (AS) fraction was extracted with $\mathrm{NaOH}$ and sodium borohydride. Total carbohydrates were determined by the phenol sulfuric acid procedure. The amount of $1,3-\beta$-D-glucan in the AI fraction was estimated by measuring the release of reducing sugars.

The amount of $\mathrm{N}$-acetylglucosamine was determined as previously described [29]. Briefly, the Paracoccidioides $\mathrm{Pb} 01$ yeast cells enriched cell wall fraction was subsequently hydrolyzed in $\mathrm{HCl}$ and neutralized with $\mathrm{NaOH}$. The sample was added to solution A and followed by solution B. Absorbance at $520 \mathrm{~nm}$ was measured and compared to absorbance values from a standard curve of glucosamine taken through the same reactions.

\section{Fungus cell wall integrity analysis}

CFW and CR (Sigma Biochemical) were utilized to stain the Paracoccidioides Pb01 and Pb18 cell wall, in order to 
show the effect of OenB by means of the fluorescence of the stain. Paracoccidioides was grown in liquid FavaNetto's medium at $36^{\circ} \mathrm{C}$ for $72 \mathrm{~h}$ with or without $0.32 \mathrm{M}$ of OenB. Briefly, the cells were fixed in $100 \%$ methanol at $-80^{\circ} \mathrm{C}$ for $20 \mathrm{~min}$ and then at $-20^{\circ} \mathrm{C}$ for $20 \mathrm{~min}$, and they were then washed and centrifuged. The cells were collected, stained with $100 \mu \mathrm{g} / \mathrm{mL}$ CFW and CR in PBS for $15 \mathrm{~min}$ and washed with PBS. The specimens were analyzed under a fluorescence microscope (Zeiss Axiocam MRc - Scope A1).

\section{RDA libraries data accession}

The RDA data from this study is available on the EST database (dbEST) at http://www.ncbi.nlm.nih.gov/nucest/? term $=$ under series LIBEST_028147 Paracoccidioides oenoteinB 90 up Library, LIBEST_028146, Paracoccidioides oenoteinB 90 down Library, LIBEST_028149 Paracoccidioides oenoteinB 180 up Library and LIBEST_028148 Paracoccidioides oenoteinB 180 down Library.

\section{Additional files}

\section{Additional file 1: Figure S1. Graph plotted to demonstrate the} statistically enriched $\mathrm{GO}$ functions with up- or down-regulated genes after exposure to the Oen B. Functional classification of Paracoccidioides CDNAs derived from RDA experiments. The percentage of each functional category is shown. The percentage of occurrence of each gene in relation to the total number of genes from the libraries was calculated and shown Additional file 2: Table S1. The functional classification was based of MIPS functional annotation scheme. Each functional class is represented as a color-coded segment and expressed as a percentage of the total number of ESTs in each library.

Additional file 2: Table S1. Percentage of ESTs up and down regulated genes of Paracoccidioides yeast cells treated with OenB by 90 and $180 \mathrm{~min}$.

\section{Authors' contributions}

PFZC conducted all the experiments described in the manuscript; SCS and PHF provided extracts of oenothein B for experiments; PKT participated in the polymer dosage experiments; CLB contributed to the RDA experiments; WSM contributed to the bioinformatic analysis; CMAS and MP contributed to the preparation of the manuscript. MP designed the study, provided support and co-wrote the manuscript. All authors contributed to the discussion of results. All authors have read and approved the final manuscript.

\section{Competing interests}

The authors declare that they have no competing interests.

\section{Acknowledgments}

This work at Universidade Federal de Goiás was supported by International Foundation for Sciences (IFS), Conselho Nacional de Desenvolvimento Científico e Tecnológico (CNPq), Fundação de Amparo à Pesquisa do Estado de Goiás (FAPEG) and by Financiadora de Estudos e Projetos (FINEP). P.F.Z.C. was supported by a fellowship from Coordenação de Aperfeiçoamento de Pessoal de Nível Superior (CAPES).

\section{Author details}

'Departamento de Bioquímica e Biologia Molecular, Laboratório de Biologia Molecular, Instituto de Ciências Biológicas, ICBII, Campus II, Universidade Federal de Goiás, C.P. 131, 74001-970 Goiânia, GO, Brazil. ²Laboratório de Bioatividade Molecular, Instituto de Química, Universidade Federal de Goiás, Goiânia, GO, Brazil. ${ }^{3}$ Instituto de Informática, Universidade Federal de Goiás, Goiânia, Goiás, Brazil.
Received: 27 August 2013 Accepted: 1 October 2013

Published: 12 October 2013

\section{References}

1. Pfaller MA, Diekema DJ: Epidemiology of invasive candidiasis: a persistent public health problem. Clin Microbiol Rev 2007, 20:133-163.

2. Dismukes WE: Antifungal therapy: lessons learned over the past 27 years. Clin Infect Dis 2006, 42:1289-1296.

3. Zhai $B$, Lin $X$ : Recent progress on antifungal drug development. Curr Pharm Biotechnol 2011, 8:1255-1262.

4. Cos P, Vlietinck AJ, Berghe DV, Maes L: Anti-infective potential of natural products: how to develop a stronger in vitro 'proof-of-concept'. J Ethnopharmacol 2006, 3:290-302.

5. Stein AC, Alvarez S, Avancini C, Zacchino S, von Poser G: Antifungal activity of some coumarins obtained from species of Pterocaulon (Asteraceae). J Ethnopharmacol 2006, 107:95-98.

6. Agüero M, Alvarez S, Luna L, Feresin G, Derita M, Tapia A, Zacchino S: Antifungal activity of Zuccagnia punctata Cav. Evidences for the mechanism of action. Planta Med 2007, 73:1074-1080.

7. Pacciaroni A, Gette M, Derita MA, Ariza Espinar L, Gil RR, Zacchino SA, Silva $\mathrm{GL}$ : Antifungal activity of Heterothalamus alienus metabolites. Phytothery Res 2008, 4:524-528.

8. Auricchio MT, Bacchi EM: Eugenia uniflora L. "brazilian cherry" leaves: pharmacobotanical, chemicaland pharmacological properties. Rev Inst Adolfo Lutz 2003, 62:55-61.

9. Schmeda-Hirschmann G, Theoduloz C, Franco L, Ferro E, de Arias AR: Preliminary pharmacological studies on Eugenia uniflora leaves: xanthine oxidase inhibitory activity. J Ethnopharmacol 1987, 2:183-186.

10. Kiss AK, Bazylko A, Filipek A, Granica S, Jaszewska E, Kiarszys U, Kósmider A, Piwowarski J: Oenothein B's contribution to the anti-inflammatory and antioxidant activity of Epilobium sp. Phytomed 2010, 18:557-560.

11. Brandelli CLC, Giordani RB, De Carli GA, Tasca T: Indigenous traditional medicine: in vitro anti-giardial activity of plants used in the treatment of diarrhea. Parasitol Res 2009, 104:1345-1349.

12. Consolini AE, Baldini OAN, Amat AG: Pharmacological basis for the empirical use of Eugenia uniflora L. (Myrtaceae) as antihypertensive. J Ethnopharmacol 1999, 66:33-39.

13. Coutinho HDM, Costa JGM, Falcão-Silva VS, Siqueira-Júnior JP, Lima EO: Potentiation of antibiotic activity by Eugenia uniflora and Eugenia jambolanum. J Med Food 2010, 4:1024-1026.

14. National Health Surveillance Agency (Anvisa): Brazilian pharmacopeia. In, Volume 5. 4th edition. Edited by Atheneu. São Paulo, Brazil; 2003.

15. National Health Surveillance Agency (Anvisa): Brazilian resolution, RDC No 267. Brazil: Ministry of Health; 2005.

16. Funatogawa $\mathrm{K}$, Hayashi $\mathrm{S}$, Shimomura $\mathrm{H}$, Yashida $\mathrm{T}$, Hatano $\mathrm{T}$, Ito $\mathrm{H}$, Hirai Y: Antibacterial activity of hydrolyzable tannins derived from medicinal plants against helicobacter pilory. Microbiol Immunol 2004, 48:251-261

17. Aoki K, Maruta H, Uchiumi F, Hatano T, Yoshida T, Tanuma S: A macrocircular ellagitannin, oenothein $B$, suppresses mouse mammary tumor gene expression via inhibition of poly (ADP-ribose) glycohydrolase. Biochem Biophys Res 1995, 210:329-337.

18. Lesuisse D, Berjonneau J, Ciot C, Devaux P, Doucet B, Gouvest JF, Khemis B, Lang C, Legrand R, Lowinski M, Maquin P, Parent A, Schoot B, Teutsch G: Determination of oenothein $B$ as active 5-a-redutase-inhibiting principle of the folk medicine epilobium parviflorum. J Nat Prod 1996, 59:490-492.

19. Santos GD, Ferri PH, Santos SC, Bao SN, Soares CMA, Pereira M: Oenothein $B$ inhibits the expression of PbFKS1 transcript and induces morphological changes in Paracoccidioides brasiliensis. Med Mycol 2007, 7:609-618.

20. San-Blas G, Burger E: Experimental medical mycological research in Latin America - a 2000-2009 overview. Ver Iberoam Micol 2011, 1:1-25.

21. Shikanai-Yasuda MA, Queiroz-Telles F, Mendes RP, Colombo AL, Moretti ML: Guidelines in paracoccidioidomycosis. Revista da Sociedade Brasileira de Med Trop 2006, 39:297-310.

22. Travassos LR, Taborda CP: New advances in the development of vaccine against paracoccidioidomycosis. Front Microbiol 2011, 3:1-6.

23. Agarwal AK, Xu T, Jacob MR, Feng Q, Lorenz MC, Walker LA, Clark M: Role of heme in the antifungal activity of the azaoxoaporphine alkaloid sampangine. Eukariot Cell 2008, 7:387-400. 
24. Zang QY, Mao JH, Liu P, Huang QH, Lu J, Xie YY, Weng L, Zhang Y, Chen Q, Chen SJ, Chen Z: A systems biology understanding of the synergistic effects of arsenic sulfide and imatinib in BCR/ABL-associated leukemia. Proc Natl Acad Sci USA 2009, 106:3378-3383.

25. Xu T, Feng Q, Jacob MR, Avula B, Mask MM, Baerson SR, Tripathi SR, Mohammed R, Hamann MT, Khan IA, Walker LA, Clark AM, Agarwal AK The marine sponge-derived polyketide endoperoxidase plakortide $\mathrm{F}$ acid mediates its antifungal activity by interfering with calcium homeostasis. Antimicrob Agents Chemother 2011, 55:1611-1621.

26. Yan C, Zhang ZX, Xu HH: An SSH library responsive to azadirachtin a constructed in Spodoptera litura Fabricius cell lines. J Biotechnol 2012, 1-2:115120.

27. Pastorian K, Havell L III, Byus CV: Optimization of cDNA representational difference analysis for the identification of differentially expressed mRNAs. Anal Biochem 2000, 283:89-98.

28. Hart TW, Wu X, Tatchell K: Protein phosphatase type 1 regulates ion homeostasis in Saccharomyces cerevisiae. Genet 2002, 160:1423-1437.

29. Tomazett PK, Castro NS, Lenzi HL, Soares CMA, Pereira M: Response of Paracoccidioides brasiliensis Pb01 to stressor agents and cell wall osmoregulators. Fungal Biol 2011, 1:62-69.

30. Roncero C, Durán A: Effect of calcofluor white and congo red on fungal cell wall morphogenesis: In vivo activation of chitin polymerization. J Bacteriol 1985, 163:1180-1185.

31. Wood PJ: Specificty in the interaction of direct dyes with polysaccharides. Carbohydr Res 1980, 81:271-287.

32. Herth W: Calcofluor white and congo red inhibit chitin microfibril assembly of Poteriochromonas: evidence for a gap between polymerization and microfibril formation. J Cell Biol 1980, 87:442-450.

33. Yamaguchi MU, Silva APB, Ueda-Nakamura T, Dias Fllho BP, Silva CC, Nakamura CV: Effects of a thiosemicarbazide camphene derivative on Trichphyton mentagrophytes. Molecules 2009, 17:1796-1807.

34. Kanetsuna F, Carbonell LM, Azuma I, Yamamura Y: Biochemical studies on the thermal dimorphism of Paracoccidioides brasiliensis. J Bacteriol 1972, 110:208-218.

35. Restrepo A: The ecology of Paracoccidioides brasiliensis: a puzzle still unsolved. Sabouraudia 1985, 23:323-334.

36. San-Blas G: Paracoccidioidomycosis and its etiologic agent Paracoccidioides brasiliensis. J Med Vet Mycol 1993, 2:99-113.

37. Carbonell LM, Kanetsuna F, Gil F: Chemical morphology of glucan and chitin in the cell wall of the yeast phase of Paracoccidioides brasiliensis. J Bacteriol 1970, 101:636-642.

38. San-Blas G: The cell wall of fungal human pathogens: it's possible role in host-parasite relationships. Mycopathol 1982, 79:159-184.

39. Silva SP, Felipe MSS, Pereira M, Azevedo MO, Soares CMA: Phase transition and stage-specific protein synthesis in the dimorphic fungus Paracoccidioides brasiliensis. Exp Mycol 1994, 18:294-299.

40. Brown GD: Dectin-1: a signallinh non-TLR pattern-recognition receptor. Nat Rev Immuno/ 2006, 1:33-34.

41. Shapiro BM, Stadtman ER: Glutamine synthetase (E. coli). Methods Enzymol 1970, 17A:910-922.

42. Kramer KJ, Koga D: Insect chitin: physical state, synthesis, degradation and metabolic regulation. Insect Biochem 1986, 16:851-877.

43. Chandra H, Basis SF, Gupta M, Banerjee N: Glutamine synthase encoded by $\mathrm{g} \ln \mathrm{A}-1$ is necessary for cell wall resistance and pathogenicity of Mycobacterium bovis. Microbiol 2010, 12:3669-3677.

44. Bailão AM, Schrank A, Borges CL, Dutra V, Molinari-Madlum EEWI, Felipe MSS, Mendes-Giannini MJS, Martins WS, Pereira M, Soares CMA: Differential gene expression by Paracoccidioides brasiliensis in host interaction conditions: Representational difference analysis identifies candidate genes associated with fungal pathogenesis. Microbes Infec 2006, 8:2686-2697.

45. Kaneko Y, Ohno H, Kohno S, Miyazaki Y: Micafungin alters the expression of genes related to cell wall integrity in Candida albicans biofilms. Jpn J Infect Dis 2010, 63:355-357.

46. Rogg LE, Fortwendel JR, Juvvadi PR, Lilley A, Steinbach WJ: The chitin synthase genes chs $A$ and chs $C$ are not required for cell wall stress response in the human pathogen Aspergillus fumigates. Bioch Bioph Res Comm 2011, 3:549-554.

47. Kurita T, Noda Y, Takagi T, Osumi M, Yoda K: Kre6 protein essential for yeast cell wall $\beta-1,6-$ glucan synthesis accumulates at sites of polarized. J Biol Chem 2011, 286:7429-7438.
48. Roemer T, Bussey $\mathrm{H}$ : Yeast beta-glucan synthesis: KRE6 encodes a predicted type II membrane protein required for glucan synthesis in vivo and for glucan synthase activity in vitro. Proc Natl Acad Sci USA 1991, 88:11295-11299.

49. Gilbert NM, Donlin MJ, Gerik KJ, Specht CA, Djordjevic JT, Wilson CF, Sorrell C, Lodge JK: KRE genes are required for b-1,6-glucan synthesis, maintenance of capsule architecture and cell wall protein anchoring in Cryptococcus neoformans. Mol Microb 2010, 2:517-534.

50. Dwek RA: Glycobiology: toward understanding the function of sugars. Chem Rev 1996, 2:683-720.

51. Madi A, Free SJ: a-1,6-mannosylation of N-linked oligosaccharide present on cell wall proteins is required for their incorporation into the cell wall in the filamentous fungus Neurospora crassa. Eukaryot Cell 2010, 9:1766-1775.

52. Klis FM, Mol P, Hellingwerff K, Brul S: Dynamics of cell wall structure in Saccharomyces cerevisiae. FEMS Microbiol Rev 2006, 26:239-256.

53. Sertil O, Vemula A, Salmon SL, Morse RH, Lowry CV: Direct role for the Rpd3 complex in transcriptional induction of the anaerobic DAN/TIR genes in yeast. Mol Cell Biol 2007, 27:2037-2047.

54. Uccelletti D, Farina F, Rufini S, Magnelli P, Abeijon C, Palleschi1 C: The Kluyveromyces lactis a-1,6-mannosyltransferase KIOch1p is required for cell-wall organization and proper functioning of the secretory pathway. FEMS Yeast Res 2006, 6:449-457.

55. Ueno K, Namiki Y, Mitani H, Yamaguchi M, Chibana $H$ : Differential cell wall remodeling of two chitin synthase deletants $\triangle c h s 3 A$ and $\triangle c h s 3 B$ in the pathogenic yeast Candida glabrata. FEMS Yeast Res 2011, 11:398-407.

56. Bowman SM, Free SJ: The structure and synthesis of the fungal cell wall. Bioessays 2006, 28:799-808.

57. Latgé JP: The cell wall: a carbohydrate armour for the fungal cell. Mol Microbiol 2007, 66:279-290.

58. Bard M, Lees ND, Turi T, Craft D, Cofrin L, Barbuch R: Sterol synthesis and viability of erg11 (cytochrome P450 lanosterol demethylase) mutations in Saccharomyces cerevisiae and Candida albicans. Lipids 1993, 28:963-967.

59. Abe F, Usui K, Hiraki T: Fluconazole modulates membrane rigidity, heterogeneity, and water penetration into the plasma membrane in Saccharomyces cerevisiae. Biochemistry 2009, 48:8494-8504.

60. Martin SW, Konopka JB: Lipid raft polarization contributes to hyphal growth Candida albicans. Eukariot Cell 2004, 3:675-684

61. Saville SP, Lazzell AL, Monteagudo C, Lopez-Ribot JL: Engineered control of cell morphology in vivo reveals distinct roles for yeast and filamentous forms of Candida albicans during infection. Eukariot Cell 2003, 2:1053-1060.

62. Martel CM, Parker JE, Bader O, Weig M, Gross U, Warrilow AGS, Rolley N, Kelly DE, Kelly SL: Identification and characterization of four azoleresistant erg3 mutants of Candida albicans. Antimicrob Agent Chem 2010, 54:4527-4533.

63. Alcazar-Fuoli LA, Melladoa E, Garcia-Efreona G, Lopez BJL, Grimalt JO, Cuenca-Estrella JM, Rodriguez-Tudela JL: Ergosterol biosynthesis pathway in Aspergillus fumigatus. Steroids 2008, 73:339-347.

64. Dallabona C, Marsano RM, Arzuffi P, Ghezzi D, Mancini P, Zeviani M, Ferrero I, Donnini C: Sym1, the yeast ortholog of the MPV17 human disease protein, is a stress-induced bioenergetic and morphogenetic mitochondrial modulator. Hum Mol Gen 2010, 19:1098-1107.

65. Jeon J, Yang JE, Kim S: Integration of evolutionary features for the identification of functionally important residues in major facilitator superfamily transporters. PLOS Comput Biol 2009, 5:1-12.

66. Vermitsky JP, Edlind TD: Azole resistance in Candida glabrata: coordinate upregulation of multidrug transporters and evidence for a Pdr1-like transcription factor. Antimicrob Agents Chemother 2004, 48:3773-3781

67. Holmes AR, Lin YH, Niimi K, Lamping E, Keniya M, Niimi M, Tanabe K, Monk BC, Cannon RD: ABC transporter Cdr1p contributes more Cdr2p does to fluconazole efflux in fluconazole-resistant Candida albicans clinical isolates. Antimicrob Agents Chemother 2008, 52:3851-3862.

68. Tanabe K, Lamping E, Adachi K, Takano Y, Kawabata K, Shizuri Y, Niimi $M$, Uehara $Y$ : Inhibition of fungal $A B C$ transporters by unnarmicin $A$ and unnarmicin $C$, novel cyclic peptides from marine bacterium. Biochem Biophy Res Commun 2007, 364:990-995.

69. Sharma M, Manoharlal R, Shukla S, Puri N, Prasad T, Ambudkar SV, Prasad R: Curcumin modulates efflux mediated by yeast $A B C$ multidrug 
transporters and is synergistic with antifungals. Antimicrob Agents Chemother 2009, 53:3256-3265.

70. Holmes AR, Keniya MV, Ivnitski-Steele I, Monk BC, Lamping E, Skalar LA Cannon RD: The monoamine oxidase A inhibitor clogyline is a broadspectrum inhibitor of fungal $A B C$ and MFS transporte efflux pump activies which reverses the azole resistance of Candida albicans and Candida glabrata clinical isolates. Antimicrob Agents Chemother 2012, 3:1508-1515.

71. Bal AM: The echinocandins: three useful choices or three many? J Antimicrob Agents Chemother 2010, 35:13-18.

72. Nakai T, Uno J, Ikeda F, Tawara S, Nishimura K, Miyaji M: In vitro antifungal activity of micafungin (FK463) against dimorphic fungi: comparison of yeast-like and mycelia forms. Antimicrob Agents Chemother 2003, 47:1376-1381.

73. Rodríguez-Brito S, Niño-Vega G, San-Blas G: Caspofungin affects growth of Paracoccidioides brasiliensis in both morphological phases. Antimicrob Agents Chemother 2010, 54:5391-5394.

74. Brummer E, Castãneda E, Restrpo A: Paracoccidioidomycose: an update. Clin Microbiol Rev 1993, 6:89-117.

75. Zambuzzi-Carvalho PF, Cruz AHS, Silva LKS, Goes A, Soares CMA, Pereira M The malate synthase of Paracoccidioides brasiliensis $P b 01$ is required in the glyoxylate cycle and in the allantoin degradation pathway. Med Mycol 2009, 31:1-11.

76. Da Silva Neto BR, de Fátima da Silva J, Mendes-Giannini MJ, Lenzi HL, de Almeida Soares CM, Pereira M: The malate synthase of Paracoccidioides brasiliensis is a linked surface protein that behaves as an anchorless adhesin. BMC Microbiol 2009, 9:272

77. Pereira M, Song Z, Santos-Silva LK, Richards MH, Nguyen TT, Liu J, de Almeida Soares CM, da Silva Cruz AH, Ganapathy K, Nes WD: Cloning, mechanistic and functional analysis of a fungal sterol C24methyltransferase implicated in brassicasterol biosynthesis. Biochim Biophys Acta 2010, 1801:1163-1174.

78. Cruz AH, Brock M, Zambuzzi-Carvalho PF, Santos-Silva LK, Troian RF, Góes AM, Soares CM, Pereira M: Phosphorylation is the major mechanism regulating isocitrate lyase activity in Paracoccidioides brasiliensis in yeast cells. FEBS J 2011, 278:2318-2332.

79. Fava-Netto C: Estudos quantitativos sobre a fixação do complemento na Blastomicose Sul-Americana com antígenos polissacarídicos. Arq Cir Clín Exp 1955, 18:197-254.

80. Restrepo A, Jiménez B: Growth of Paracoccidioides brasiliensis yeast phase in a chemically defined culture medium. J Clin Microbiol 1980, 12:279-281.

81. Freshney R: Culture of animal cells. In A manual of basic technique. Edited by Alan R. New York: Liss; 1987:117.

82. Lisitsyn N, Lisitsyn N, Wigler M: Cloning the differences between two complex genomes. Science 1993, 12:946-951.

83. Hubank M, Schatz DG: Identifying difference in mRNA expression by representational difference analysis of cDNA. Nucleic Acids Res 1994, 25:5640-5648

84. Ewing B, Hillier L, Wendl MC, Green P: Base-calling of automated sequencer traces using PHRED. I. Accuracy assessment. Genome Res 1998, 8:175-185.

85. Crossmatch Program Database: http://www.macvector.com/Assembler/ trimmingwithcrossmatch.html.

86. Huang X, Madan A: CAP3: a DNA sequence assembly program. Genome Res 1999, 9:868-877.

87. Laboratório de Biologia Molecular/UFG Database: http://www.lbm.icb.ufg.br/ joomlaLBM/.

88. GeneBank Database: http://www.ncbi.n/m.nih.gov.

89. Altschul SF, Madden TL, Schäffer AA, Zhang J, Miller W, Lipman DJ: Gapped BLAST and PSI-BLAST: a new generation of protein database search programs. Nucleic Acids Res 1997, 25:3389-3402.

90. Paracoccidioides Structural Genome Database: http://www.broad.mit.edu/ annotation/genome/paracoccidioides_brasiliensis/.

91. Blast2GO Program Database: www.blast2go.org.

92. Conesa A, Göts S, García-Gómez JM, Terol J, Talón M, Robles M: Blast2GO: a universal tool for annotation, visualization and analysis in functional genomics research. Bioinformatics 2005, 21:3676-3686.
93. Götz S, García-Gómez JM, Terol J, Williams TD, Nagaraj SH, Nueda MJ, Robles M, Talón M, Dopazo J, Conesa A: High-throughput functional annotation and data mining with the Blast2GO suite. Nucleic Acids Res 2008, 36:3420-35.

94. MIPS Functional Catalog Database: http://mips.helmholtz-muenchen.de/ genre/proj/ustilago/listSearch.html?.

95. Bookout L, Cummins CL, Mangelsdorf DJ, Pesola JM, Kramer MF: Highthroughput real-time quantitative reverse transcription PCR. In Current protocols in molecular biology. Edited by Ausubel FM, Brent R, Kingston RE, Moore DD, Seidman JG, Smith JA, Struhl K. John Wiley \& Sons; 2006:1-28. 15.8. Chapter 15: United 15.8. DOl: 10.1002/0471142727.mb1508s73.

doi:10.1186/1471-2180-13-227

Cite this article as: Zambuzzi-Carvalho et al:: Transcriptional profile of Paracoccidioides induced by oenothein $\mathrm{B}$, a potential antifungal agent from the Brazilian Cerrado plant Eugenia uniflora. BMC Microbiology 2013 13:227.

\section{Submit your next manuscript to BioMed Central and take full advantage of:}

- Convenient online submission

- Thorough peer review

- No space constraints or color figure charges

- Immediate publication on acceptance

- Inclusion in PubMed, CAS, Scopus and Google Scholar

- Research which is freely available for redistribution

Submit your manuscript at www.biomedcentral.com/submit
C Biomed Central 